\title{
Inside Russia's Imperial Relations: The Social Constitution of Putin-Kadyrov Patronage
}

\author{
Julie Wilhelmsen
}

The prominence of patronage has been evident from the beginning of this century in Moscow's rule over Chechnia through the intermediary Akhmad Kadyrov. Moreover, it has increased as a source of political power since president Akhmad Kadyrov was killed in 2004 and his son Ramzan Kadyrov inherited this position. Moscow became more and more inclined to govern Chechnia through a patron-client relationship between the Russian President, Vladimir Putin, and the Head of Chechnia, Ramzan Kadyrov. Ramzan's firm rule over Chechnia itself has been attained through the extension of patronage practices into the organization of the security, political, and economic spheres. Judging by recent commentary on Russian affairs, these claims may look like pushing in wide open doors. ${ }^{1}$ Moreover, the inner workings of Putin's Russia have already been convincingly conceptualized as personalistic, closed networks of patronage. ${ }^{2}$ This article's ambition, however, is to go beyond stating the obvious, that patronage is important in Putin's relations with Kadyrov, and show how such relations acquire a local cultural imprint and how they are socially constituted.

My point of departure is that the current organizing principle in Moscow's relations with certain regions in the Russian Federation is best grasped by the concept of imperial hierarchy. Empires are characterized by rule through intermediaries and the existence of distinctive contractual relations between cores and their peripheries. ${ }^{3}$ Within this larger understanding of Moscow's current relations with Chechnia as imperial, I suggest and substantiate the current distinct contractual relationship between the Russian center and Chechnia as one based on patronage informed by kinship. I argue that the Putin-Kadyrov relationship is a generic case of a patron-client connection, but highlight the local imprint that such bonds acquire by tracing how Chechen

1. See for example Ekaterina Sokirianskaia, "Is Chechnya taking over Russia?," The New York Times, August 17, 2017; Mark Galeotti's blog, https://inmoscowsshadows. wordpress.com/about/ for example "Kadyrov the Terrible? Is he really going, or is this just a curtain call?," at https://inmoscowsshadows.wordpress.com/2016/02/27/kadyrovthe-terrible-is-he-really-going-or-is-this-just-a-curtain-call / (last accessed September 18, 2018); Amy Knight, "Putin’s Monster” New York Review of Books, May 19, 2017, at http:// www.nybooks.com/daily/2017/05/19/putins-monster-ramzan-kadyrov/ (last accessed September 18, 2018).

2. Alena V. Ledeneva, Can Russia Modernise? Sistema, Power Networks and Informal Governance (Cambridge, Eng., 2013), Henry E. Hale, Patronal Politics: Eurasian Regime Dynamics in Comparative Perspective (New York, 2015), see also Henry E. Hale, "How Nationalism and Machine Politics Mix in Russia,” in Pål Kolstø and Helge Blakkisrud, eds., The New Russian Nationalism: Imperialism, Ethnicity and Authoritarianism, 2000-15 (Edinburgh, 2016), 221-48.

3. Daniel B. Nexon, and Thomas Wright, "What's at Stake in the American Empire Debate,” American Political Science Review 101, no. 2 (May 2007): 253-71. 
kinship practices inform this case. ${ }^{4}$ It is kinship's role in social organization, as an ideational and practical resource in a larger collective setting that is studied here, not kinship as a set structure of blood relations. ${ }^{5}$ The tentative answer to the question of how patronage informed by kinship has become relevant and why it prevails builds on the claim that social use and practice has a recursive effect on such relations. Like all social relationships, patronclient bonds informed by kinship are confirmed and strengthened by being exercised. ${ }^{6}$ More specifically, they prevail because they are cultivated from above via private practices of personal recruitment, direct appointment, nonformal communication, and resource allocation, but also because they are constituted as the legitimate bond between rulers, intermediaries, and people through public practices, both linguistic and material.

In the first section of this article, the claim that Moscow's current relations with Chechnia are best understood as imperial is substantiated. The stage is set for enquiring into how patronage informed by kinship has become the essence of this distinctive contractual relationship. Then the article continues by revisiting the heritage of kinship in Chechen social and political life before it moves on to illustrate how Akhmad Kadyrov's fragile rule, and through him Russia's imperial rule of Chechnia, was re-established through a patron-client relationship informed by kinship. The third section investigates in more detail how Putin's patronage over Ramzan Kadyrov is substantiated through the exchange of gifts between patron and client, but also how it is constituted and sustained through public linguistic and material practices that affirm kinship as well as other Chechen cultural codes. In the fourth section I show how formal federal relations and ties between Russia and Chechnia have waned as Kadyrov's sovereignty over Chechnia has increased and question the balance of power in the father-son relationship that has developed between Putin and Ramzan Kadyrov. Finally, in the conclusion I point to the challenges such a relationship poses for Moscow's rule over the Russian Federation as a whole.

\section{What Kind of Rule and How is it Established?}

With the increasing concentration of power in the hands of the Russian presidency, analyzing center-periphery relations through conceptualizations of Russia as a "federative system" has lost currency. ${ }^{7}$ As of today, there are also obvious differences in how Moscow governs the eighty-five federal subjects

4. Patron-client relation can be defined, as it is on WebRef, as "a mutually obligatory arrangement between an individual who has authority, social status, wealth, or some other personal resource (the patron) and another person who benefits from his or her support or influence (the client)," at http://www.webref.org/anthropology/p/patron_ client_relationship.htm (last accessed September 18, 2018).

5. Iver B. Neumann, Kristin Haugevik and Jon Harald Sande Lie, "Kinship in International Relations: Introduction and Framework," in Kristin Haugevik and Iver B. Neumann, eds., Kinship in International Relations (Abingdon, Oxon, Eng., 2019).

6. Patrick Thaddeus Jackson, Civilizing the Enemy: German Reconstruction and the Invention of the West (Ann Arbor, 2006).

7. Helge Blakkisrud, The Governor's Last Stand: Federal Bargaining in Russia's Transition to Appointed Regional Heads, 2005-2009 (Oslo, 2015), Paul J. Goode, The Decline of Regionalism in Putin's Russia: Boundary Issues (Milton Park, 2011), Jeffrey Kahn, Federalism, 
(including Sevastopol and Crimea) that make up the Russian Federation. Chechnia is in many ways an "outlier" compared to the other regions. The ideal-typical concept of empire that receives much attention in the current international relations debate clearly has particular relevance if we zoom in on this one center-periphery relation. Moscow's rule over this tiny republic conforms nicely with classical and more recent conceptualizations of imperial relations.

Building on Max Weber, Michael Doyle, and Ronald Grigor Suny, George Steinmetz defines empires as "political organizations that are expansive, militarized, and multinational, and that place limits on the sovereignty of the polities in their periphery." ${ }^{8}$ The classical definitions of empire tend to underline the hierarchical, inequitable relationship between the metropole and a disadvantaged periphery, as well as the role of intermediaries. ${ }^{9}$ Expanding on this, more recent scholarly work emphasizes the diversity between the units in the periphery and the techniques imperial regimes use to regulate such diversity. Jane Burbank and Frederick Cooper, for example, argue that empires, in contrast to nation states, seek to reproduce difference in the periphery rather than cultivate sociocultural homogenization. ${ }^{10}$ In a similar vein, Daniel Nexon suggests that empires are composite arrangements that rely extensively on "rule through intermediaries" and are characterized by patterns of government in which the center subordinates communities through "heterogeneous contracting between imperial cores and constituent political communities."11 As we shall see below, there is little doubt that Moscow's rule over Chechnia through the Kadyrovs is an example of the ideal-typical "rule through intermediaries." Moreover, the social contract through which Chechnia has been subordinated to Moscow since the beginning of this century has been distinct and different from those that bind other federal subjects to Moscow, mainly because Chechnia was the only subject that sought independence from Moscow and attempted to secede after the Soviet Union came apart. In the terms of Suny, we could say that the Second Chechen War was an "imperial project" proper, involving the establishment of full sovereignty by a center over a distinct and

Democratization, and the Rule of Law in Russia (Oxford, 2002), Cameron Ross, Federalism and Democratisation in Russia (Manchester, 2002).

8. George Steinmetz "Empires and Colonialism," http://www.oxfordbibliographies. com/view/document/obo-9780199756384/obo-9780199756384-0090.xml (no longer available); Max Weber, Economy and Society: An Outline of Interpretive Sociology, 2 vols, eds. Guenther Roth and Claus Wittich (Berkeley, 1978); Michael W. Doyle, Empires (Ithaca, 1986); Ronald Grigor Suny, “The Empire Strikes Out: Imperial Russia, “National” Identity, and Theories of Empire," in Ronald Grigor Suny and Terry Martin, eds., A State of Nations: Empire and Nation-making in the Age of Lenin and Stalin (Oxford, 2001), 23-66.

9. "Empire is a particular form of domination or control between two units set apart in a hierarchical, inequitable relationship, more precisely a composite state in which a metropole dominates a periphery to the disadvantage of the periphery," in Suny, "The Empire Strikes Out," 25. Similarly, according to Reus-Smit, empires are authoritarian systems of alien rule grounded in "regimes of unequal entitlements," in Christian Reus-Smit, Individual Rights and the Making of the International System (Cambridge, Eng., 2013), 12.

10. Jane Burbank and Frederick Cooper, Empires in World History: Power and the Politics of Difference (Princeton, 2010).

11. Daniel B. Nexon, The Struggle for Power in Early Modern Europe: Religious Conflict, Dynastic Empires, and International Change (Princeton, 2009), 253. 
subordinate periphery..$^{12}$ On the heels of the second Chechen War, a distinct contract between the federal center and Chechnia developed through the Putin/Kadyrov axis, as I argue here, built on kinship-informed patronage. This, along with the fact that there is little connection between Chechnia and other subjects in the periphery of the Federation makes it a good example of the "hub-and-spoke system of authority" typical of empires. According to Andrew Phillips, vertical integration (between center and periphery) and horizontal segregation (between imperial segments) form imperial statecraft's two interlinked imperatives. ${ }^{13}$ The task here will be to enquire into how vertical incorporation has been achieved in the case of Chechnia and show how patronage informed by kinship has come to constitute the content of the distinctive contract between the Russian center and Chechnia.

As Nexon notes "empires face specific problems of legitimating their control ... Empires often best navigate these cross pressures by engaging in 'multivocal' or 'polyvalent' signaling: by projecting different identities and commitments to discrete audiences." 14 Elaborating on this, Phillips suggests that hubs, such as Moscow, acquire power over subordinate communities, such as Chechnia, by relying on indirect rule and by building on and incorporating local ideas and normative resources. The making of the bond between the imperial core and the subordinate communities is hard work and necessitates extensive imperial intervention to modify existing collective identities to conform to imperial designs. "The curatorship of collective identities," Phillips suggests, "through customization practices involving the appropriation, adaptation and reorganization of indigenous ideational resources to shore up imperial authority-has historically been key to the business of empire building." 15

Phillips theorizes the process of building imperial relations as conscious and top-down. Customization practices involve two processes, according to Phillips. Empire builders undertake creative initiatives that are productive for the categories of difference among subject groups; they differentiate and define these groups. Then in the next phase, empire builders institutionalize them by inscribing them into practices of imperial governance. ${ }^{16}$ The case studied in this article suggests that less conscious and top down processes are at work, wherein the initiatives from the subject group seem to define as much those from the empire builder's hand. Moreover, the ideational resources in the subject group place clear limits on creativity in the center. Therefore, this account will start from "the bottom up" by looking at kinship in the Chechen subject group. As Jeppe Mulich notes, state transformation in historical colonialism was sometimes driven by colonizers and imperial administrators,

12. Ronald Grigor Suny, “Ambiguous Categories: States, Empires and Nations,” PostSoviet Affairs 11, no. 2 (1995): 193-94.

13. Andrew Phillips, "Making Empires: Hierarchy, Conquest and Customization," in Ayşe Zarakol, ed., Hierarchies in World Politics (Cambridge, Eng., 2017), $43-65$.

14. Nexon, The Struggle of Power in Early Modern Europe, 254. Also, Burbank and Cooper emphasize that modern empires have to exercise "responsive rule" over the populations they seek to govern; see their chapter 10.

15. Phillips, "Making Empires: Hierarchy, Conquest and Customization," 48-49.

16. Ibid., 50-51. 
who claimed territories and created new institutions. Other parts of state transformation, however, were driven by the very people facing potential incorporation by outside forces: in attempting to stave off such incursions, they refashioned their own polities and political institutions. ${ }^{17}$

Whether the process is more bottom up or top down, the result in terms of an imperial relationship is fairly similar. Through processes of customization, "traditional" local intermediaries are empowered and become critical brokers linking the center to the subordinate community and the basis for the narrow compacts between the imperial elite and the intermediary are laid. At the same time, certain forms of collective identities are frozen in place, making anti-imperial mobilization less probable. ${ }^{18}$ The fundamental and underlying understanding is always that neither the imperial center nor the subordinate community can be understood as pre-existing social units. This implies that the Putin-Kadyrov relationship analyzed below should not be considered as hinging on a static copy of Chechen kinship, but as a dynamic reinvention. The explicit argument throughout what follows in the next sections is that the Chechen "difference"-kinship-informs the social basis of the current PutinKadyrov patron-client relationship and the Russo-Chechen imperial compact more generally.

Recent literature on the workings of the Russian political system successfully capture current-day center-periphery relations based on informal networks in conceptualizations such as sistema or patronal politics. ${ }^{19}$ As laid out in the work of Alena Ledeneva or Henry Hale, the more secret and isolated machinations of informal networks of personal acquaintance in the Russian polity, for example, are crucial to our understanding of its inner workings. Other articles document well the prevalence of such relations in Russia. ${ }^{20}$ This literature, however, as well as, for example, the classical work on the internal relations of the Soviet ruing bureaucracy by Henry Rigby, fails to explain how these relations are socially constituted. ${ }^{21}$ It disregards the fact that the actors in patronal networks also are social actors embedded in a larger social context: they legitimize their actions and relations not only within these networks, but also before a larger audience in the Russian polity. ${ }^{22}$ Hale has presented patronal politics as the opposite of what Benedict Anderson captured

17. Jeppe Mulich, "Transformation at the Margins: Imperial Expansion and Systemic Change in World Politics," Review of International Studies 44, no. 4 (October 2018): 694-716.

18. Phillips, "Making Empires: Hierarchy, Conquest and Customization."

19. For sistema, see Alena V. Ledeneva, Can Russia Modernise? Sistema, Power Networks and Informal Governance (Cambridge, Eng., 2013). For patronal politics, see Henry E. Hale, Patronal Politics: Eurasian Regime Dynamics in Comparative Perspective (New York, 2014).

20. Alexander Baturo and Johan A. Elkink, "Dynamics of Regime Personalization and Patron-Client Networks in Russia, 1999-2014,” Post-Soviet Affairs 32, no. 1, (2016): 75-98; Vladimir Gel'man, "The Vicious Circle of Post-Soviet Neopatrimonialism in Russia," PostSoviet Affairs 32, no. 5 (2016): 455-73.

21. Henry (T.H) Rigby, Political Elites in the USSR: Central Leaders and Local Cadres from Lenin to Gorbachev (Aldershot, Eng., 1990).

22. On legitimation, see Jackson, Civilizing the Enemy. 
in his concept of "imagined communities." ${ }^{23}$ He then explains Putin's embrace of nationalism in 2014 merely as an isolated event, an instrumental move to shore up a potential crack in "machine politics." ${ }^{24}$ This article works from the understanding that Putin has always needed to speak and cater to certain "rhetorical common places" among the members in patronal networks, as well as to such ideational resources in the wider communities he has sought to govern. ${ }^{25}$ This has probably been particularly crucial when trying to establish personal acquaintance with persons with a very different social and cultural background (such as the Kadyrovs), and through such persons to rule over a community that has been subjected to war by the Russian center twice since 1991. By building on the recent contributions to the literature on empires laid out above, the account below will show that the patron-client relationship of Putin and Kadyrov is not only of a closed, personal nature, but built on locally-embedded collectives and constantly changing kinship practices. More generally, the account will enlarge our understanding of how the bonds within patronal networks are established socially and how they are legitimized and communicated to a wider yet discrete community.

\section{Heritage and the Building of Patronage over Chechnia}

During the Russian colonization of the Caucasus, the mountain peoples of the northeastern Caucasus were last to give in. Organized in independent clans but united under the slogan of Gazavat (Holy war against Christian colonization) and the leadership of Imam Shamil, Chechens, Avars and other Muslim peoples in the region withstood Russian imperial power until 1864. ${ }^{26}$ Ever since, what we today refer to as Chechnia has formally been part of the Russian Empire, the Soviet Union, or the Russian Federation, although with different administrative borders and labels attached. Despite this formal attachment, lower-level Chechen social organization has been continuously informed by ideas and practices of kinship. In addition to the clan (taip), many years of Gazavat during colonization resulted in the emergence of another social structure informed by kinship, often overlapping the clan, namely the Sufi brotherhoods (vird). ${ }^{27}$ Although they did not stay the same, taips and virds survived Soviet times as organizing principles in Chechen society.

While formal political, and to some extent, also the so-called traditional kinship practices broke down before and during the First Chechen War (19941996), other social structures based on ideas of kinship shaped Chechen society in war. Prime amongst these was a group of independent but connected

23. Benedict Anderson, Imagined Communities: Reflections on the Origin and Spread of Nationalism (London, 1983).

24. Hale, "How Nationalism and Machine Politics Mix in Russia."

25. Ronald R. Krebs and Patrick Thaddeus Jackson, "Twisting Tongues and Twisting Arms: The Power of Political Rhetoric," European Journal of International Relations 13, no. 1 (2007): 35-66.

26. John F. Baddeley, The Russian Conquest of the Caucasus (London, 1908).

27. A taip is an extended family network that originates and develops from one or several tribal villages, so-called auls, in Anna Zelkina, In Quest for God and Freedom: The Sufi Response to the Russian Advance in the North Caucasus (New York, 2010), 14-20. 
warlords. Each of these warlords commanded a group of men that often, but not always, came from the same village and were related through practices of kinship. The efficiency, loyalty, and dedication that such an organization inspired was a key asset for the Chechen forces in their war against Russia and goes a long way in explaining their military victory. When elections were held in January 1997, the Chechen commander-in chief, Aslan Maskhadov, who was the mastermind behind the Chechen victory in Grozny in August 1996, was elected president and head of the Chechen republic of Ichkeria. But even as president in "peacetime," Maskhadov sought to exert power via kinship-informed patronage instead of strengthening formal state institutions: the practice of appointing members of the war-time resistance, his "brothers in arms," prevailed in his cabinet of ministers. His rule as head of the Ichkerian state was from the very beginning conditioned and limited by the continued existence of groups of fighters that were loyal primarily to their particular warlords. ${ }^{28}$ According to Charles Fairbanks, Maskhadov's position increasingly resembled that of medieval kings in their struggles with the great vassals, "because they were kings, they had more responsibilities, which they often could discharge only by giving someone part of the royal estate." ${ }^{29}$ Maskhadov frequently had to buy the warlords' support by cutting into Ichkeria's resources or income. One example was the way in which he condoned instead of punished trade in hostages and illegal oil extraction. As a result, the warlords in Chechnia saw their units as their own fiefdoms, in peace as well as wartime. President Maskhadov, on the other hand, became dependent on revenue flows from Moscow. Maskhadov's attempt to revert the relation to the warlords in favor of the Ichkerian state by sacking the warlord ministers in summer 1998 only resulted in the subsequent formation by the warlords of a Shura: a council that challenged Maskhadov's authority as head of state. ${ }^{30}$ When push came to shove, the civil war on everybody's lips at that time never came to pass. Maskhadov's National Guard was never used against the warlords. The bonds of loyalty between former brothers in arms prevailed over their commitment to move Ichkeria toward regular statehood.

Moscow's relations with Chechnia from 1999 onwards were built through kinship-based patronage. Under cover of being an "anti-terrorist campaign," the launching of the Second Chechen War in October 1999 was a patrimonial act in the Weberian sense: the Russian ruler simply claimed ownership to the land that Russia used to rule. In June 2000, Moscow introduced rule by decree in Chechnia, suspending its status as one of the (at that time) eightynine federal subjects of the Russian Federation by denying it the right to elect its own government. My interest here is how such patrimonial politics feed on kinship. I argue that the change of tack in relations implicit in this initial act was substantiated over time by customization practices drawing on kinship

28. Miriam Lanskoy, “Chechnya’s Internal Fragmentation, 1996-1999," The Fletcher Forum of World Affairs 27, no. 2 (Summer-Fall 2003): 185-205.

29. Charles H. Fairbanks, "Weak States and Private Armies," in Mark R. Beissinger and Crawford Young, eds., Beyond State Crisis? Postcolonial Africa and Post-soviet Eurasia in Comparative Perspective (Washington, D.C., 2002): 139.

30. Julie Wilhelmsen, "Between a Rock and a Hard Place: The Islamisation of the Chechen Separatist Movement,” Europe-Asia Studies 57, no. 1 (January 2005): 35-59. 
as an ideational resource. Importantly, Moscow did not prevail in the Second Chechen War, hardly militarily and certainly not in terms of extending formal federal institutional structures into Chechnia. Just like in the Manchu and British Empires, which relied fundamentally on indigenous military resources to conquer and later police their empires, the Chechen pro-Russian Kadyrovtsy were instrumental in quenching armed resistance in Chechnia. ${ }^{31}$ Moreover, Moscow needed a middleman. Akhmad Kadyrov, former Mufti of Chechnia (1995-99) and one of the commanders in the Chechen resistance during the First Chechen War, was installed in this position. Just as conquering elites in early modern times could not afford to stay indifferent to religious matters in their efforts to establish bonds with middlemen in the periphery, Russian elites in the twenty-first century could not remain indifferent to religious but especially kinship matters if they wanted to rule Chechnia after the two post-Soviet wars. ${ }^{32}$ Indeed, failing to co-opt kinship into Russo-Chechen patronage could have resulted in making this core Chechen difference into a powerful mobilizing tool against Russian rule. At the same time choosing a former Chechen Mufti and one of the brothers-in-arms as middleman granted the Russian center access to symbolic capital that became decisive in attempts to legitimize its rule in Chechnia.

Akhmad Kadyrov's radical move from brother-in-arms with Maskhadov and other Chechen warlords to Moscow's middleman started with a secret meeting in Moscow in June 1999 with Vladimir Putin. By summer 2000, a partial military victory in Chechnia was achieved, and Akhmad Kadyrov was appointed by Putin as the head of the pro-Moscow civil administration in Chechnia. Kadyrov's social standing and power at the time of his appointment was marginal. ${ }^{33}$ In Chechnia, the appointment triggered a final exclusion of Kadyrov from the circle of former brothers-in-arms. Perceived as a traitor, there had already been several attempts on his life and now Maskhadov publicly named him a "traitor," "an enemy of the Chechen people," and called for the death penalty against him. ${ }^{34}$ According to Kadyrov, his administration had no control to speak of apart from an agent in every village. In Chechnia he trusted nobody but "his own," and even these he was not quite sure of. ${ }^{35}$ In the Russian center, few but Vladimir Putin supported him, and Putin's choice of Kadyrov was probably based on the latter's self-centered opportunism, a quality that is characteristic for the members of the Russian sistema. ${ }^{36}$ Attachment to the Russian center was not only initiated by personal appointment, but allegedly also upheld through personal communication with Vladimir Putin

31. Phillips, "Making Empires," 12.

32. Nexon, The Struggle for Power in Early Modern Europe, 261.

33. On the precarious standing and status of Akhmad Kadyrov in Chechnia see also Kimberley Zisk Marten, Warlords: Strong-Arm Brokers in Weak States (Ithaca, 2012), 108.

34. "Russia appoints Chechen leader," $B B C$ News, June 12, 2000, at http://news.bbc. co.uk/2/hi/europe/787811.stm (last accessed September 18, 2018).

35. Anne Nivat, Chienne de Guerre: A Woman Reporter behind the Lines of the War in Chechnya (New York, 2001), 245.

36. Marten, Warlords: Strong-Arm Brokers in Weak States, and Ledeneva, Can Russia Modernise: Sistema, Power Networks and Informal Governance. 
via direct telephone calls to Kadyrov's house. ${ }^{37}$ In Chechnia, Kadyrov worked from his home base in Gudermes, surrounded by a small clientele of his relatives (including his father and cousins). ${ }^{38}$

During the first years after his appointment, Kadyrov's weak rule over Chechnia was evident in the continued Russian military presence and the blatant use of fraud to secure victory in the March 2003 referendum on a new constitution that affirmed Russian sovereignty over Chechnia, as well as in the presidential election in October 2003, which made him the new Chechen president. At the same time, Moscow's dependency on the proxy in Chechnia was obvious: Putin offered to give Chechnia, under Kadyrov's leadership, "autonomy in the broadest sense of the word." 39 This was the time when Moscow's relations with other federal subjects were being worked back into a "power- vertical" by streamlining regional laws with federal laws, curtailing the powers of the upper house of the Russian Federal Assembly, and appointing presidential representatives to seven new "Federal Okrugs."

Looking more closely at how such a relationship of mutual dependency in a situation of insecurity and weakness shaped Kadyrov's attempts to broaden his rule over Chechnia, the prominence of kinship-based patronage emerges as the key vehicle. Within the superficial, formal institutional structure that had been erected around Akhmad Kadyrov's administration, Kadyrov's own men gradually replaced people directly subordinated to Moscow. A cabinet shakeup in summer 2003 only resulted in the re-appointment of those who were dismissed. Through this process the ministers became directly tied to Akhmad Kadyrov because they were dependent on him personally for their re-appointment and the Chechen government became "100 percent proKadyrov." ${ }^{40}$ There were still appointees loyal to others than Kadyrov in the Chechen administration, such as Prime Minister Anatoly Popov, an ethnic Russian with close ties to the Russian military establishment, but the pattern was clear already at this point. To increase Akhmad Kadyrov's strategic control over Chechnia and at the same time side-line the Russian forces and agencies that were engaged in Chechnia outside of his control, a private army, the Kadyrovtsy, was built. Even the name itself indicates the extent to which kinship was the symbolic and practical resource in building this army. According to Tomas Smid and Miroslav Mares, the core of the Kadyrovtsy was established already when Akhmad Kadyrov was the Mufti of Chechnia and a part of the separatist movement. ${ }^{41}$ When Kadyrov switched sides, the Kadyrovtsy became his personal security guard commanded by his son, Ramzan, and later after his election as president, they were turned into the "Presidential Security Service.” Their ranks were replenished through a series of amnesties

37. Nivat, Chienne de Guerre, 246.

38. Georgi M. Derluguian, Bourdieu's Secret Admirer in the Caucasus: A World-System Biography (Chicago, 2005), 255.

39. James Hughes, Chechnya: From Nationalism to Jihad (Philadelphia, 2007), 121.

40. Lawrence Uzzell, “Kadyrov Orchestrates Personnel Shakeup in Grozny,” Chechnya Weekly 4 (21), June 12, 2003.

41. Tomáš Šmid and Miroslav Mareš , “'Kadyrovtsy:’ Russia’s Counterinsurgency Strategy and the Wars of Paramilitary Clans," Journal of Strategic Studies 38, no. 5 (2015): 650-77. 
beginning in 2002. Akhmad Kadyrov had allegedly convinced Putin that it was possible to lure many of the Chechen armed insurgents over to their side. ${ }^{42}$

Although in early 2003 Putin said that the Kadyrov government's local police and security forces would take over the responsibility for policing and preserving order in Chechnia, the results of the first rounds of amnesties were meagre..$^{43}$ Only his son Ramzan's "personal touch" made the Kadyrovtsy into a superior military force in Chechnia. The situation in Akhmad's Chechnia looked more like a civil war, with warlords constantly carrying out attacks on Chechen police and security services. In May 2004, a bomb killed Akhmad himself during the Victory Day celebration in Grozny. Ramzan's answer to the question of how he was going to avenge the killing of his father was cold: "the person who I had to kill, I have already killed. And those who stand behind him, I will kill them all down to the last man, as long as I am not killed or shot myself. I will kill as long as I live." ${ }^{44}$ The loyalty to kin and obligation to revenge were to become core rationales behind the ensuing build-up of forces loyal to Ramzan in Chechnia. They also became core features of the relationship between the Russian ruler and the new Chechen middleman.

\section{The Substantiation of Putin's Patronage over Chechnia}

Putin's choice of ruling Chechnia through Akhmad's son Ramzan reflected not only his degree of dependency on Kadyrov for strategic control over Chechnia, but also the need to play to the particular Chechen difference. From the very beginning, the relationship was publicly framed as being of a private, even intimate nature and each side made commitments to the other with reference to family bonds. In a TV-interview, Ramzan re-called his first meeting with Putin in the Kremlin the same day that his father was killed:

Imagine, I was a young man, twenty-six or twenty-seven years. I didn't even understand why he invited me there. I saw that Putin was very emotionally upset (clip where Putin with Ramzan dressed in a sports suit by his side announces the death of Chechen president Akhmad Kadyrov, noting that the slain Chechen president "took responsibility for his nation with honor and courage") ... he said he looked upon my Dad as a friend, as someone close, as a comrade-in-arms, as someone he could rely on . . . those were his words. I asked him to give me the opportunity to continue the war, to let me continue to fight against the terrorists, the terrorists and the extremists. And he promised, I will give you this task ... . and we fought, we continued, with

42. “Strana Spetsnaz [Spetsnaz country]," Novaya Gazeta, July 25, 2011, at http:// www.novayagazeta.ru/society/47063.html (last accessed January 24, 2017.)

43. Sophie Lambrochini, “Chechnya: After Kadyrov's Inauguration, Doubts Remain,” $R F E / R L$, October 20, 2003, at http://www.rferl.org/a/1104725.html (last accessed January 30, 2017).

44. “Рамзан Кадыров рассказал журналу GQ, что такое военный стиль, что и дальше будет убивать и что Путин-красавчик [Ramzan Kadyrov told the journal GQ what martial style is, that he will continue to kill and that Putin is a beauty]," Novosti NEWSru.com, October 5, 2005, at http://www.newsru.com/russia/05oct2005/kadyrov. html (last accessed January 24, 2017.) Author’s translation. 
weapons in our hands ... and then we built this (pointing to beautiful high arch in a new building in Grozny where the interview was shot). ${ }^{45}$

Whether such recollections provide the correct version of "what actually happened" is beside the point. The crucial thing is that this bond between ruler and middleman was constituted and confirmed publicly as a kinship-like bond through words and images, also from Putin's side. There is not even an attempt to frame the relationship as formal. Rather, it was publicly presented as one of personal proximity and indebtedness. It is also noteworthy how Putin in his short summation of Akhmad's achievements ticks the boxes of the two prime virtues in Chechen society: honor and courage, and then endorses Ramzan's request to lead the violent fight against the terrorists. Such merger of Chechen kinship and cultural codes into the new Russo-Chechen compact is not an isolated episode. Playing to kinship and martial duty has been a constant when Ramzan and Putin address the public. ${ }^{46} \mathrm{In}$ an interview with Putin, the interviewer starts by referring to a statement by Ramzan that he is personally indebted to Putin for his life and then asks Putin how he conceives of this relation. Putin answers: "I look upon him as a son, we have in recent years developed friendly, really friendly, personal relations and I am convinced, this has played a tremendously positive role in the life of the Chechen nation and for Russia. Precisely because of and thanks to his position, Chechnia managed to get out of the war ...",47

While Putin had to incorporate and take on concepts of kinship to establish his relationship to Ramzan, something which is potentially very unpopular among Russians, he simultaneously transferred the symbolic capital of kinship over into his rule over Chechnia in this next phase.

The personal recruitment of Ramzan to leadership in Chechnia following his father's death did get a formal cover in his promotion to first deputy premier following the election of Alu Alkhanov as republican President in 2004. However, the formal hierarchy of the position in Chechnia was secondary. It was Ramzan that was entrusted with coordinating and leading the mass-scale program to rebuild infrastructure in Chechnia. The reconstruction effort that transformed Grozny from a wasteland into a functioning city was funded largely by aid from the federal government. ${ }^{48}$ Ramzan personally

45. "Kadyrov about the first meeting with Putin," Ukrainian News, September 18, 2014, at https://www.youtube.com/watch?v=Xz3cXoohS7E (last accessed May 5, 2016). Author's translation.

46. Answering the question on Putin's role in the Chechen crises in 2005 Ramzan answers: "Putin is the man. He cares more for Chechnia than any other republic. When my father died, he came in person to the graveyard . . Putin ended the war." Novosti NEWSru. com, October 5, 2005, at http://www.newsru.com/russia/05oct2005/kadyrov.html (last accessed September 18, 2018). Author's own translation.

47. Vladimir Putin, “Владимир Путин-Рамзан Кадыров мне как сын [Vladimir Putin-Ramzan Kadyrov is like a son to me]," interview by Chechen State Television, August 2, 2016, YouTube video, at https://www.youtube.com/watch?v=HEl4Mt1CtkQ (last accessed May 30, 2018). Author's translation.

48. It is impossible to know how much money was spent rebuilding Chechnia, particularly Grozny, and how much of this sum was allocated through the Russian federal budget to Chechnia. By various estimates Grozny City cost half a billion dollars to build ("The Family. A Film about Ramzan Kadyrov, Whom Putin Calls a Son,” Open Russia, 
administered this vast sum of money allocated, allegedly with Putin's acceptance of his diverting part of that cash flow for his own personal use. ${ }^{49}$ Some have claimed that Ramzan takes one third of the budget for himself. ${ }^{50}$ Thus, the personal appointment of Ramzan and the bond created between him and Putin after Akhmad's death was strengthened and upheld by the allocation of resources directly to Ramzan. While such allocations create loyalty to and dependency on the patron at the individual level, they simultaneously, through the physical rebuilding of the destroyed Chechen capital, contribute to reshaping the collective image of Russian rule from killer to benefactor among the Chechens, making patronage more acceptable.

Apart from the flow of money that Ramzan was allowed to tap into, a flow of arms was directed into Ramzan's private army. When the Kadyrovtsy were legalized as Interior Ministry units in 2004, it provided a basis for financing and supplying them with arms. This also happened with several other units of forces which were given different formal names and were armed by the federal center, but which in reality were paramilitary entities subordinate to Ramzan. ${ }^{51}$ As Kimberly Marten notes, these changes did not necessarily signal increased federal control over Chechnia. ${ }^{52}$ On the contrary, Ramzan's power increased when his private army could regroup under a formal federal label and enjoy legitimate status under Russian law. While the compact taking shape seems to empower Ramzan as well as certain Chechen cultural practices, it would be wrong to think of it as a one-way exchange. Ramzan's troops have to wear the federal mantel. Chechens have to accept the formal presence of Russian Federal agencies on their soil, if only in name. In this way the radical identity difference between Russia and Chechnia, a core product of the two Chechen wars, is being masked and Russian rule publicly legitimated. ${ }^{53}$

There are several other good examples of public acts that serve to substantiate and legitimize the Russo-Chechen compact. Among the twelve federal orders and medals Ramzan has been awarded since 2002, the most prestigious ones are the Order of Courage in 2003, Hero of the Russian Federation in 2004, Order for Merit to the Fatherland in 2006, and the Zhukov medal, which he has been awarded twice. He has furthermore received a whole row of public and agency specific orders and medals, as well as Chechen ones, more than three dozen in all, according to International Crisis Group..$^{54}$ The Russian medals awarded Ramzan over the years serve to constitute him personally as nothing less than a Russian hero. Through these acts, Putin's patronage over

May 25, 2015, YouTube video at https://www.youtube.com/watch?v=krXLTNNeNZs (last accessed January 24, 2017).

49. Liz Fuller, "The Unstoppable Rise of Ramzan Kadyrov," Radio Free Europe/ Radio Liberty, January 19, 2015, at http://www.rferl.org/content/profile-ramzan-kadyrovchechnya-russia-putin/26802368.html (last ccessed January 24, 2017).

50. Open Russia, "The Family."

51. International Crisis Group (ICG), "Chechnya: The Inner Abroad,” Europe Report No. 236, (June 30, 2015), 4, at http://www.refworld.org/docid/559294054.html (last accessed January 24, 2017).

52. Marten, Warlords: Strong-Arm Brokers in Weak States, 110.

53. Julie Wilhelmsen, Russia's Securitization of Chechnya: How War Became Acceptable (London, 2017).

54. ICG, "Chechnya, the Inner Abroad." 
Ramzan is legitimized to Russian audiences. At the same time, these symbolic gifts not only cement the loyalty and indebtedness of Ramzan to Putin on the personal level, but also constitute the idea of Russia as something more agreeable to Chechen audiences; their leader and their ways are rewarded and not punished by Russia. The cultural compromise has to be noted, however. While the awards are Russian, the practice of awarding a man for martial bravery resonates strongly with Chechen cultural codes, such as Yah, the Chechen honor code for men that compels you to be best, bravest in battle, and first where help in needed. ${ }^{55}$

While Putin has allocated money, guns, and degrees to Ramzan, Ramzan's prime gift to Putin has been a military force and protection. Putin's first promise to the Russian people when he became Prime Minister in 1999 was to crush the "terrorists" in Chechnia. This was achieved only with the help of the Kadyrovtsy. The gift of force and protection from Ramzan has taken on a new form over the years. The services of Ramzan's private army have been offered outside the borders of Chechnia and in defense of Russia. During the Russo-Georgian war in 2008, several thousand Chechen soldiers served as border guards along the Abkhaz and South Ossetian borders and the Vostok battalion fought in South Ossetia on the Russian side. ${ }^{56}$ Similar services were offered during the war in Ukraine. Inspecting 20,000 fully-armed Chechen soldiers on the December 28, 2014 in the Belimkhan sport complex in Grozny (with Putin overlooking from posters), Ramzan explained that

\begin{abstract}
Each of them received an order saying that today they will depart to fulfil a military order given by the Supreme Commander ... decisions are made by the Supreme Commander, we are just checking how we are prepared to fulfil assigned tasks. I think we will be glad to fulfil any order. We are ready to deploy to any place in the world that the President may ask us to go. I have no doubt that we will not upset him and will fulfil his order $100 \% \ldots$ all of them are ready to voluntarily fulfil any order of the Supreme Commander any place in the world. ${ }^{57}$
\end{abstract}

When Ramzan offers his services to Putin he publicly confirms his own, and through him Chechnia's, subordination to Putin's Russia. At the same time, subordination acquires a local Chechen imprint: it happens with reference to personal ties and indebtedness and is manifested in martial services. The personal nature of the subordination as well as the resonance with Chechen blood feud practices is stunning if one considers that the two killings in Moscow of Putin's staunchest critics, the journalist Anna Politikovskaya (2006) and the politician Boris Nemtsov (2015), were most probably carried out by Kadyrov's men.

The Russo-Chechen compact has also been substantiated through positive popular representations of Vladimir Putin in Chechnia. Putin's status

55. Amjad M. Jaimoukha, The Chechens: A Handbook (London, 2004), 134.

56. Stacy Closson, "The North Caucasus after the Georgia-Russia Conflict," Russian Analytical Digest 51 (December 5, 2008), 2-5.

57. Ramzan Kadyrov, "20,000 of Kadyrov's Soldiers Are Ready to Kill Ukrainians if Putin Will Give the Order," Live News, December 29, 2014, Youtube video at https://www. youtube.com/watch?v=zwZ1yWkhh_s (last accessed June 1, 2016). 
has been transformed from an enemy into a hero of the Chechen people. The main street in Grozny was renamed from Prospekt Pobeda (Victory Street) to Prospekt V.V. Putina. From the top of two of the five skyscrapers erected in Grozny city, both featuring a lighted sign along the front reading, "We love the Prophet Mohammad," as Akhmad Kadyrov and Vladimir Putin smile down at the Chechen people. Ramzan Kadyrov constantly affirms his admiration and subordination to Putin in public speeches to the Chechen people. On public holidays, portraits of Ramzan and Akhmad Kadyrov and of Putin are displayed. ${ }^{58}$ At the same time, Ramzan edits out national memories that divide Chechens from Russia, such as Stalin's 1944 deportation of hundreds of thousands of Chechens and Ingush to Central Asia. ${ }^{59}$ Taken together these public practices confirm and constitute Chechen loyalty to Putin as a person, through the Kadyrov family. Simultaneously, Putin becomes part of the Kadyrov family, as well as of the quasi-Islamic community that is taking shape in Chechnia. This "presence" of the Russian president contributes to condoning and normalizing Kadyrov's current rule over Chechnia. Simultaneously, Chechen identity and cultural practices are converted, if not to say perverted, into something new, building on the old. ${ }^{60}$

It is thus fair to suggest that the Russo-Chechen compact that has developed since 1999 is a narrow bargain and has a distinctive content. It hinges on a patronal connection between Putin and Ramzan involving the private exchange of appointments and resources. But this connection is also built, sustained, and legitimized to a wider audience though public words, images, and practices expressing family, loyalty, honor, and martial bravery at the core of the relationship. While these are not the cultural codes that Chechens used to know but rather a merger and a compromise, the codes of the subordinate community have made a strong imprint on the current compact. Moreover, Russia's imperial attempt has been more generative for Kadyrov than destructive.

\section{The Surge of Client Power}

Putin's success in subordinating Chechnia through kinship-informed patronage has its price. The Russian federal state has gradually ceded its monopoly on the use of force in this Russian territory. Through presidential decrees issued in February and August 2006, the regional Interior Ministry forces controlled by Ramzan were given "direct leadership” over all counterterrorist

58. “В Чечне празднование Дня России проходит при повышенных мерах безопасности [In Chechnia the Celebration of Russia Day Takes Place in Conditions of Enhanced Security],” Kavkazskii Uzel, June 12, 2013 at http://www.kavkaz-uzel.ru/ articles/225547/ (last accessed January 24, 2017).

59. "В Чечне отмечается День памяти и скорби [The Day of Memory and Grief is Celebrated in Chechnia]," Kavkazskii Uzel, May 10, 2013, at http://www.kavkaz-uzel.eu/ articles/223996/ (last accessed May 30, 2018).

60. Uwe Halbach, “Chechnya's Status within the Russian Federation: Ramzan Kadyrov's Private State and Vladimir Putin's Federal "Power Vertical," SWP Research Paper No. 2 (May 2018): 16-18, at https://www.swp-berlin.org/en/publication/chechnyas-statuswithin-the-russian-federation/ (last accessed May 30, 2018). 
activities in the North Caucasus, implying total operational dominance over federal Defense Ministry and Interior Ministry forces in Chechnia. ${ }^{61}$ In line with Kadyrov's wishes, 20,000 Russian troops were withdrawn from Chechnia in connection with the abolishment of the counter-terrorism regime in 2009. In October 2009, command over operational headquarters in Chechnia was transferred from the federal Interior Ministry to the regional FSB, which was led by a Chechen, Aleksandr Sulimov. ${ }^{62}$ Kadyrov's claim to total and exclusive sovereignty over Chechen territory was amply illustrated in his April 2015 order to Chechen security forces to shoot to kill if troops from other parts of Russia tried to carry out operations on the republic's territory without his consent. ${ }^{63}$ Other signs of declining formal federal rule over Chechnia is that neither the Federal Investigative Committee nor the Accounts Chamber seem to be able to engage in any cases in Chechnia on an independent basis. ${ }^{64}$ Moreover, the Russian President's Council on Human Rights Chairman Mikhail Fedotov's explicit warnings that the work of human rights organizations in Chechnia should not be hampered have gone totally unheeded. Human rights organizations cannot work in Chechnia today. ${ }^{65}$

Over the past several years, there have also been signs that Ramzan's sovereign zone extends beyond the Chechen borders with several examples of his troops carrying out what one might call private policing functions in Russia proper. Ramzan's policemen often have special permission and can travel in Russia with weapons and without restrictions on their actions. ${ }^{66}$ Many of the violent incidents that have taken place along the trail of these men are related to Ramzan's efforts to establish full control over Chechnia and take revenge on "critics" and "traitors." Judging by the cases that have come to light in the Russian press, Ramzan's people can act with impunity and are out of reach for federal courts and security agencies. ${ }^{67}$

61. Marten, Warlords: Strong-Arm Brokers in Weak States, 117.

62. Mairbek Vatchagaev, "FSB Assigned Control Over Operations in Chechnya and the North Caucasus," Eurasia Daily Monitor, October 19, 2009 at http:// www.jamestown.org/programs/edm/single/?tx_ttnews\%5Btt_news\%5D=35621\&tx_ ttnews\%5BbackPid\%5D=485\&no_cache=1\#.VdxbyXkw-JA (last accessed January 30, 2017).

63. Paul Sonne, "Chechen president Ramzan Kadyrov gives shoot-to-kill order on outside forces," The Wall Street Journal, April 23, 2015, at https://www.wsj.com/ articles/chechen-president-ramzan-kadyrov-gives-shoot-to-kill-order-on-outsideforces-1429812489 (last accessed May 30, 2018).

64. Sergei Bobrov, “Bastrykhin’s Humiliation,” The Interpreter, December 18, 2013 (originally published by Novaya Gazeta, December 7, 2013), at http://www.interpretermag. com/bastrykins-humiliation/ (last accessed January 24, 2017).

65. Sasha Sulim, "Human rights defenders from "Memorial” in Caucasus are abducted, imprisoned, killed," Meduza, January 17, 2018, at https://meduza.io/slides/ pravozaschitnikov-iz-memoriala-na-kavkaze-pohischayut-sazhayut-v-tyurmu-ubivayutpochemu-ih-tak-zhestoko-presleduyut (last accessed May 30, 2018).

66. Ivan Nechepurenko, "FSB Officers Go on Strike after Release of Chechen Cops, Report Says,” The Moscow Times, March 24, 2013, at http://www.themoscowtimes.com/ news/article/fsb-officers-go-on-strike-after-release-of-chechen-cops-report-says/477488. html (last accessed January 24, 2017).

67. Ivan Nechepurenko, "Daughter Challenges Refusal to Question Chechen Leader over Nemtsov Death,” TASS, August 19, 2015 at http://tass.com/russia/815184 (last accessed January 24, 2017). 
The paradox of the current Russo-Chechen compact and the particular shape it has acquired is particularly visible if we study the role that Ramzan has taken on as the Russian president's personal bodyguard. When President Dmitrii Medvedev visited Dagestan in April 2010, Ramzan deployed his police and security guards to the neighboring republic to guard the central square in the capital, Makhachkala. If Russian rule over Dagestan and Chechnia were built on formal practices and federal structures, the private army of the president in a neighboring republic would never have been given the authority to carry out core policing functions in Dagestan. This raises the question of power-relations within the ruler-middleman nexus. Who rules whom when the middleman starts to police the neighboring republic? The presence of Ramzan's guards in Makhachkala was undoubtedly detrimental to increasing Moscow's rule and legitimacy over that restless and fragile republic.

The extension of Ramzan's rule in in the North Caucasus, enabled through his military force and competency, was evident during the entire Medvedev presidency. As Aglaya Snetkov notes: "the Kadyrov regime tried to claim a role for itself in shaping the direction and implementation of regional counterterrorist operations across the rest of the North Caucasus."68 From 2011 onward, Kadyrov's reach has seemed to extend all the way to Moscow in order to provide the Russian president protection from potential "color-revolutions." ${ }^{69}$ During the large-scale anti-regime demonstrations in Moscow in autumn 2011, there were rumors that Kadyrov's bodyguard regiment, which allegedly is permanently stationed at the President Hotel in Moscow just in front of the Interior Ministry building, would be used against the protesting masses. ${ }^{70}$ The episode demonstrates not only Kadyrov's presence and ability to offer his services to Putin in the capital, but also suggests that Putin might have come to rely more on Kadyrov's men than his "own" federal police forces to protect him in this allegedly dangerous situation.

Many interpreted the April 2016 establishment of a National Guard in Russia, a new federal force meant to replace the Kadyrovtsy and curb Ramzan's power, as an answer to this problem. Yet this is very unlikely because Victor Zolotov, the head of the National Guard, was allegedly chosen, among other reasons, because he is on good terms with Ramzan Kadyrov. ${ }^{71}$ Indeed, in his annual call-in show that year, Putin, responding to a critical question about his alliance with the controversial Kadyrov, once again confirmed his support for him. He reminded the Russian audience that even if Ramzan Kadyrov once "conducted a partisan war against us. . .Chechnia should be with the Russian

68. Aglaya Snetkov, Russia's Security Policy under Putin: A Critical Perspective (Abingdon, Oxon, Eng., 2014), 177.

69. Thomas Ambrosio, "Russia,” in Donnacha Ó. Beacháinis and Abel Polese, eds., The Colour Revolutions in the Former Soviet Republics: Successes and Failures (London, 2010), 136-56.

70. Nechepurenko, "FSB Officers Go on Strike.”

71. Valery Dzutsati, "Creation of Russian National Guard Could Affect Kremlin Policies in the North Caucasus," Eurasia Daily Monitor 13, no. 75, April 18, 2016, at http://www. refworld.org/docid/5724db074.html (last accessed January 24, 2017). 
people and be part of Russia." 72 Thus, Russian rule over Chechnia through Kadyrov was yet again legitimized and made reasonable to the Russian public. On balance, however, the dependency seems to be tilting in the direction of the client. Just like Maskhadov in the period between the two wars in Chechnia, or the Russian Tsars who relied on cultivating the Cossacks as a martial vanguard in their attempts at conquering the Caucasus, Putin might very well be faced with revolt against his rule from his Chechen son and comrade-in-arms if he moves far beyond the current contract. ${ }^{73}$

In the larger picture of Moscow's rule over the Russian Federation, the biggest problem with today's imperial form of rule over Chechnia is that it is not only distinctive and narrow, but also unique. The evolution of the RussoChechen compact since the beginning of this century has consolidated certain cultural practices. Through Moscow's cultivation of the Kadyrovs and the Kadyrovtsy, the Chechens have been reinvented as a "martial race." Moreover, they have become even more inclined to connect and act within and through their own networks of trusted kin. In this, the Chechen "difference" within the Russian Federation has been transformed and amplified. Such cultivation of distinctive regional identities and practices could have been a "useful" setup for Moscow if it were replicated in relation to other subordinate communities in the Federation in an "effective" hub and spoke system, as they were in the British Empire, and indeed in early Soviet times. It would give ample room to divide and rule, because the subordinate communities in the periphery could not unite. Nevertheless, in the current system, where only one subordinate community has been given such a distinctive, narrow contract, Moscow does not have such opportunities. Indeed, one could argue that the most distinctive collective contractual relations in today's Russia beyond the more private relations inside the patronal networks are between Putin and the Russian population (a much broader community that spans across regional borders) and between Putin and the federal security agencies (a community that spans across regional borders and has been at war with Chechnia and Kadyrov for more than two decades). ${ }^{74}$

The brazen murder of Nemtsov in February 2015 is a logical extension of the Russo-Chechen compact and Ramzan's martial obligations within this compact. After all, the liberal oppositionist Nemtsov was one of Putin's (and Ramzan's) staunchest critics. His dead body at the Kremlin's doorstep could have been just another gift to cement the Putin- Ramzan relationship. For Putin, the President of the Russian Federation, such a gift has grave implications, however. Not only has it forced him yet again to prioritize protection of his "son" at the expense of enforcing federal law and empowering the federal security agencies. It also threatens the social contract Putin has with the Russian people. Unfortunately, the brute murder of one's enemies has become close to a normal practice in Ramzan's Chechnia. They have not, however, in

72. Vladimir Putin, “Direct Line with Vladimir Putin,” April 14, 2016, Video at http:// en.kremlin.ru/events/president/news/51716 (last accessed June 1, 2017).

73. Baddeley, The Russian Conquest of the Caucasus, 10-11.

74. Andrei Soldatov and Irina Borogan, The New Nobility: The Restoration of Russia's Security State and the Enduring Legacy of the KGB (New York, 2010). 
Putin's Russia. Despite the clear authoritarian traits of Putin's Russia, brute, open murder of one's enemies is still not an acceptable practice for most of the Russian public. In fact, the promise to eliminate the street crime associated with the chaotic 1990s and to create order and stability in Russia have been a key part of Putin's distinctive contractual relation with the Russian population and one of the pillars of his popularity.

Thus, while Putin's patronage of Kadyrov has seemed necessary to secure Moscow's rule over Chechnia, it challenges his core contractual relations in Russia proper. Putin knows this. While confirming his support for Kadyrov at the 2016 call-in show, his only way of legitimizing the compact in front of the Russian audience was with a reference to the Chechens as different and violent, but capable of becoming "civilized” Russians:

You know, these people are ready to risk everything, including their lives. One day he said to me, "Let me die in dignity!" They are ready for it, but only if it meets the interests of their people. Still, we need to understand who these people are. I am not even mentioning here that people in the Caucasus are hotheads. Therefore, it is not easy for these people to learn to serve as high-ranking government officials. We are all human, we all have our past. However, I believe that the head of Chechnia and the heads of other Russian regions will understand the level and degree to which they are liable to the people living on the territories they govern and to Russia in general. They must understand that extreme actions or radical statements regarding opponents do not lead to greater stability in the country. On the contrary, this is detrimental to stability. Once they understand this, and I am confident that they will as they are sincerely committed to serving national interests, there will be no statements of this kind. It may also be that there were omissions on my behalf in this respect. ${ }^{75}$

75. Putin, "Direct Line with Vladimir Putin." 